\title{
POISONOUS PLANTS OF GOA
}

\author{
K.N. Desai \\ P.E.S. College of Arts and Science, Farmagudi, Ponda, Goa 403401, \\ India
}

Goa, situated along the central West Coast of India lies in between $15^{\circ} 48^{\prime} 00^{\prime \prime}$ and $14^{\circ} 43^{\prime} 54^{\prime \prime} \mathrm{N}$ lat. and $74^{0} 20^{\prime} 13^{\prime \prime}$ to $73^{\circ} 40^{\prime} 33^{\prime \prime}$ long. The floral diversity of this region is very rich.

Pioneering work on the flora of this area in general and medicinal plants in particular have been done by scholars like Garcia de Orta, Dalgado, Dada Vaidya and Theodore Cooke (1904) during the last two centuries. Vartak (1966) and recently, Rao $(1985,1986)$ have given elaborate information regarding the flora of Goa.

It is essential to take cognisance of the fact that overuse or abuse of the medicinal constituents of plants can cause danger. In fact of the 3,00,000 species of plants described in the world, 700 are known to be causing illness in man or livestock.

Plants containing glucosides, acids or alkaloids are used as medicines. These when taken in excess often have adverse effect. The latex, white or coloured sap found in families of Apocynaceae, Asclepiadaceae, Sapotaceae, Euphorbiaceae and Papaveraceae, if used in excess always act as poison. Plants of family Araceae have calcium carbonate or oxalate crystals, which cause intense irritation of mouth and throat, as also swelling of throat and intestinal lining. This may cause suffocation or death.

Some plants containing orthophosphoric acids cause painful irritation and eruption if they come in contact with skin or mucous membrane.

There are some plants or products like seeds of Annona squamosa L. and unripe pineapple when consumed induce abortion in pregnant women.

Pollen grains of many plants like Alstonia scholaris L.R., Br., Chromolaena odorata L. King \& Robinson and many species of grasses cause bronchial allergy leading to asthma in sensitive people (Desai \& Desai , 1992).

None of the poisonous plants require eradication. Most of the plants have great medicinal value besides being used as shade trees, decorative indoor plants or beautiful garden ornamentals.

Received 16 September 1998;

Accepted 3 October 1999

The usefulness and the aesthetic satisfaction derived from them far outweigh their toxic threats. The purpose of this article is therefore to educate the common man to identify such plants so that the possible dangers of merely touching or eating are prevented.

Some plants/plant parts reported from Goa and having poisonous effect are dealt below:

Abrus precatorius L.(Fabaceae): Gunghchi (Hindi), Kunch (Ben.), Gunj (Kon.), Kundumani (Tam.). The seeds are $0.5 \mathrm{~cm}$. long, red with a black spot at one end. The chemical constituents abrin, abrine, and abrasine are intensely poisonous when injected subcutaneously in doses of $0.0005-0.0001 \mathrm{mg} . / \mathrm{kg}$. body weight (Anonymous, 1985).

Calotropis gigantea (L.) R.Br./ Calotropis procera (Ait.) R.Br. (Asclepiadaceae): Ak (Hindi), Akanda (Beng.), Rui (Konk.), Arkkam (Tam.). Both the species closely resemble each other and are found in the same regions. All parts of the plants of both the species yield latex. The latex of both the species contains some poisonous constituents which is a strong irritant to the skin and mucous membrane. Gigantin, isolated only from Calotropis gigantea is a cardiac poison (Anonymous, 1992). Cattle die eating this plant. (Desai \& Desai, 1992)

Croton tiglium L. (Euphorbiaceae): Jamaloota (Hindi), Japal (Konk.), Jaypal (Ben.), Nervalam (Tam.). It is commonly grown in gardens as an ornamental plant. The seeds contain tiglinic acids, crotonic acid and croton oil. All the chemical constituents act as drastic purgative. Even a single seed has proved to be fatal to animals including man (Anonymous, 1950).

Datura inoxia Mill./Datura metal L. (Solanaceae): Dhatura (Hindi, Beng.), Dutro (Kon.), Ummatai (Tam.). The two species can be identified on the basis of the corolla, D. inoxia has 10toothed corolla while $D$. metal has 5 toothed corolla (Rao, 1986). All parts of both the plants specially the leaves and the seeds are poisonous. The chemical constituents are hyoscine, hyoscyamine, atropine and dutarin. Hyoscine has a sedative action on the central nervous system. Dutarin is a strong intoxicant, narcotic and toxic in high doses (Dastur, 1985) and (Anonymous, 1953).

Gloriosa superba L. (Liliaceae): Kalihari (Hindi), Bishalanguli (Beng.), Vagha bachko (Kon.), Kalappaikkislangu (Tam.). The plant is a slender climber with bright red or yellow flowers, during August to October. The entire plant especially the underground tubers and roots contain colchicin which is poisonous. If eaten it produces digestive upset, nervous excitement and oral paraesthesia. Death may follow within four hours of intake (Anonymous, 1956).

Jatropa multifida L. (Euphorbiaceae): Bherenda (Hindi), Lalbherenda (Ben.), Chini erandi (Kon.) Kattunervalum (Tam.). It is cultivated in gardens as ornamental. The foliage and fruits 
contain curcin, which is poisonous. Eating of foliage and fruits cause vomiting, diarrhoea, intense stomach cramps, stupor, unconsciousness and finally death (Anonymous, 1959).

Lantana camera L. var. aculiata (L.) Mold. (Verbenaceae): Ghaneri (Kon.), Unniched (Tam.). It is a common shrub with red, orange, yellow, or pink flowers. The entire plant, especially the berries, contain polycyclic triterpenoid similar to rehmannic acid or lobelamine and lobeline. Ingestion of the plant produces severe digestive upset, bloody diarrhoea, weakness and death (Anonymous, 1962).

Gnidia glauca (Fresen.) Gilg. (=Lasiosiphon eriocephalus (Graham) Decne) (Thymeleaceae): Datpadi/Rameto (Kon.), Nachinaar (Tam.). It is a branched shrub with mottled bark (Almeida, 1990). Stem, leaves and bark are used as fish poison. Teeth get detached from the gum if the paste of the bark is applied. Known to be highly poisonous and skin irritant (Anonymous, 1962).

Rauvolfia serpentina L. Benth. Ex Kurz (Apocynaceae): Chandrabhaga (Hindi), Chandra (Beng.), Atki (Kon.), Chivanamelpodi (Tam.). It is a perennating undershrub. The roots contain many alkaloids; to mention a few, reserpine, reserpidine, reserpinine and serpentine. The roots have depressent action on the central nervous system, lowers blood pressure and has sedative action. Minimum therapeutic dose gives nasal congestion, lethargy, drowsiness, gastro-intestinal problems. Higher dose may cause flushing, insomnia, brachycardia, occasionally parkinsonism and severe mental depression which may lead to suicide (Anonymous, 1969).

Ricinus communis L. (Euphorbiaceae): Erandi (Hindi), Bherenda (Ben.), Vhadlo erand (Kon.), Amanakku (Tam.). It grows on waste land. The seeds contain recine and recinine. Toxic symptoms of recine do not appear for several hours after ingestion. It causes vomiting, colic, haemorrhage, gastroenteritis, stupor, convulsion, odema and circulatory collapse (Anonymous, 1972).

Strychnos nux-vomica L. (Loganiaceae): Baileva (Hindi), Kuchila (Ben.), Karo (Konk.), Etti (Tam.). The dried ripe seeds are poisonous and contain alkaloids like strychnine, brucine and vomicine. It acts principally on the spinal cord causing excessive reflex irritability which results in convulsions in which all the muscles of the body are involved. The respiratory muscles are also involved and as a general rule after two to three convulsions respiration fails to return. With high dose death may occur immediately resulting from paralysis of the central nervous system (Anonymous, 1976).

\section{Acknowledgement}

The author is grateful to the World Wide Fund For Nature India, Goa division for sponsoring the project on "Poisonous
Plants of Goa". Special thanks to Dr. A.G. Untawale who extended all help and guidance during this study.

\section{References}

Almeida, S.M. (1990). The Flora of Savantwadi, Scientific Publishers, Jodhpur Vol.I, 366 pp.

Anon (1950). Wealth of India, Vol.II CSIR Publication, New Delhi. pp. $383-384$

Anon (1953). Wealth of India, Vol.III CSIR Publication, New Delhi. pp. $14-18$.

Anon (1956). Wealth of India, Vol.IV CSIR Publication, New Delhi. pp. 139.

Anon (1959). Wealth of India, Vol.V CSIR Publication, New Delhi. pp. 296.

Anon (1962). Wealth of India, Vol.VI CSIR Publication, New Delhi. pp. $31 \& 36$.

Anon (1969). Wealth of India, Vol.VII CSIR Publication, New Delhi. pp. 89.

Anon (1972). Wealth of India, Vol.IX CSIR Publication, New Delhi. pp. 26.

Anon (1976). Wealth of India, Vol.X CSIR Publication, New Delhi. pp. 62 .

Anon (1985). Wealth of India, Vol.I (Revised) CSIR Publication, New Delhi. pp. 18 - 19.

Anon (1992). Wealth of India, Vol.III (Revised) CSIR Publication, New Delhi. pp. 80.

Cooke, T. (1904). Flora of Bombay, Botanical Survey of India, Howrah, Vol. II and III, 1083 pp.

Dastur, J.F. (1985). Medicinal Plants of India and Pakistan. D.B., Taraporevala Sons and Co. Private Ltd., Bombay, pp. 212.

Desai, K.D. and N.B. Desai (1992). Poisonous Plants of Goa, Report sponsored by W.W.F.-India, Goa Division (Unpublished) 45 pp. Rao, R.S. (1985). Flora of Goa, Diu, Daman, Dadra, and Nagarhaveli, Vol.I Botanical Survey of India, Howrah.

Rao, R.S. (1986). Flora of Goa, Diu, Daman, Dadra, and Nagarhaveli, Vol.II. Botanical Survey of India, Howrah.

Vartak, V.D. (1966). Enumeration of plants from Gomantak, India, MaharashtraAssociation for the cultivation of Science, Poona, $166 \mathrm{pp}$. 